\title{
Systemic Acquired Resistance Delays Race Shifts to Major Resistance Genes in Bell Pepper
}

\author{
A. M. Romero and D. F. Ritchie
}

Department of Plant Pathology, North Carolina State University, Raleigh 27695.

Current address of A. M. Romero: Cátedra de Fitopatología, Facultad de Agronomía, Universidad de Buenos Aires, Argentina.

Accepted for publication 19 August 2004.

\begin{abstract}
Romero, A. M., and Ritchie, D. F. 2004. Systemic acquired resistance delays race shifts to major resistance genes in bell pepper. Phytopathology 94:1376-1382.

The lack of durability of host plant disease resistance is a major problem in disease control. Genotype-specific resistance that involves major resistance $(R)$ genes is especially prone to failure. The compatible (i.e., disease) host-pathogen interaction with systemic acquired resistance (SAR) has been studied extensively, but the incompatible (i.e., resistant) interaction less so. Using the pepper-bacterial spot (causal agent, Xanthomonas axonopodis pv. vesicatoria) pathosystem, we examined the effect of SAR in reducing the occurrence of race-change mutants that defeat $R$ genes in laboratory, greenhouse, and field experiments. Pepper plants carrying one or more $R$ genes were sprayed with the plant defense

strains of the pathogen. In the greenhouse, disease lesions first were observed 3 weeks after inoculation. ASM-treated plants carrying a major $R$ gene had significantly fewer lesions caused by both the incompatible (i.e., hypersensitive) and compatible (i.e., disease) responses than occurred on nonsprayed plants. Bacteria isolated from the disease lesions were confirmed to be race-change mutants. In field experiments, there was a delay in the detection of race-change mutants and a reduction in disease severity. Decreased disease severity was associated with a reduction in the number of race-change mutants and the suppression of disease caused by the race-change mutants. This suggests a possible mechanism related to a decrease in the pathogen population size, which subsequently reduces the number of race-change mutants for the selection pressure of $R$ genes. Thus, inducers of SAR are potentially useful for increasing the durability of genotype-specific resistance conferred by major $R$ genes.
\end{abstract} activator acibenzolar-S-methyl (ASM) and challenged with incompatible
Management of bacterial diseases poses a serious challenge for crops at risk. Control strategies may include the utilization of genetic host resistance, agronomic practices such as the use of seed and transplants presumed free of pathogens, and chemical treatments. However, chemical treatments are not highly effective. Also, their use instills a strong selection pressure for pathogen strains that overcome the host resistance. When available, genetic resistance is considered the most economically and environmentally wise option for disease management. In many cases, host resistance is specific and determined by a gene-for-gene interaction between a resistance $(R)$ gene product in the host and an avirulence ( $a v r$ ) gene product in the pathogen. Development of cultivars with host genotype-specific resistance carrying one or more major disease $R$ genes is a long process that requires a large investment of resources as well as the identification of the initial resistance sources. Unfortunately, when a resistant cultivar of a host plant is exposed to an avirulent pathogen, there often is a shift in the composition of the pathogen population, with an increase in virulent (i.e., disease-causing) strains $(11,17)$. This leads to a coevolutionary "arms race," with the release of new cultivars carrying different $R$ genes that are subsequently overwhelmed by evolving pathogens $(1,36)$.

The use of microbial components or synthetic chemicals that induce systemic resistance may provide another management option. These inducers are not known to have a direct antimicrobial effect but, instead, induce or activate innate plant defense systems (26). The phenomenon of induced resistance has been described using various terms, including induced systemic resistance (ISR)

Corresponding author: D. F. Ritchie; E-mail address: david_ritchie@ncsu.edu

Publication no. P-2004-1020-01R

(c) 2004 The American Phytopathological Society and systemic acquired resistance (SAR). At a recent conference, it was decided that both terms may be used synonymously, although induced resistance is the more general terminology (9). SAR is used here because this terminology frequently has been applied to describe the induced resistance that we studied and report here (26).

Only a few synthetic chemicals have reached commercialization; the first introduced and best studied is 1,2,3-benzothiadiazole-7-thiocarboxylic acid- $S$-methyl-ester, common name acibenzolar-S-methyl (ASM; Actigard 50WG, Blockade 50WG; Syngenta Crop Protection Inc., Greensboro, NC), a benzothiadiazole. Because multiple defense systems in the host are activated when systemic resistance is induced, it has been proposed that pathogen resistance to SAR may be slower to develop. Recently, however, it was suggested that, in some cases, ASM might contribute to a selection pressure (3). ASM has proven effective for the control of several diseases caused by virulent (compatible) pathogens in a number of plants, including bacterial spot in pepper and tomato $(19,31)$. Little is known, however, of the effect of induced systemic defense responses on plant-pathogen interactions in the incompatible (avirulent) situation involving genotype-specific resistance. A consequence of the incompatible interaction may be new virulent race-change mutant strains of the pathogen and decreased durability of disease resistance.

We hypothesized that SAR could reduce disease severity caused by race-change mutants when a host genotype resistant to the race prevalent in the field is planted. In this scenario, the use of a chemical inducer such as ASM may increase the durability of major gene resistance. Also, Tuzun (36) highlighted the similarities and possible relationship between SAR and quantitative host resistance. Thus, using our system, it also may be possible to test the hypothesis that quantitative host resistance delays or prevents an avirulent pathogen from defeating genotype-specific 
resistance when both types of resistance are combined in a cultivar. We conducted experiments using Xanthomonas axonopodis pv. vesicatoria (38), causal agent of bacterial spot of bell pepper, to test this hypothesis. Current strategies for control of this disease include the use of copper sprays and genetic host resistance. Copper sprays are not effective under high disease-conducive environments; also, there are strains of $X$. axonopodis pv. vesicatoria resistant to copper $(21,25,28,30)$. Genetic resistance to bacterial spot in pepper is determined by a gene-for-gene interaction between host $R$ genes and pathogen $a v r$ genes (22). Four major $R$ genes $(B s 1, B s 2, B s 3$, and $B s 4)$ have been identified thus far $(5,6,14,32)$; three of them $(B s 1, B s 2$, and $B s 3)$ are available as a single gene or combinations of genes in commercial bell pepper hybrids. However, pathogen strains (i.e., races) that defeat these $R$ genes have occurred both in research plots (17) and commercial production fields $(16,27,32)$.

Our objective was to test the hypothesis that pathogen race changes to major $R$ genes and subsequent population shifts can be slowed as a result of the induction of broad-spectrum plant defenses, thus delaying the adaptation of pathogens to resistant cultivars and extending the usefulness (i.e., durability) of major $R$ genes. The frequency and time of appearance of race-change mutants in ASM-treated and nontreated pepper plants carrying major $R$ genes were determined in laboratory, greenhouse, and field experiments using two different $a v r-R$ gene combinations.

\section{MATERIALS AND METHODS}

Bacterial strains. Strains of the bacterial spot pathogen used in the experiments belong to $X$. axonopodis pv. vesicatoria (38) $(=X$. campestris pv. vesicatoria group A; 35$)$. Bacteria were maintained in $20 \%$ glycerol at $-80^{\circ} \mathrm{C}$ for long-term storage, and grown on modified sucrose peptone agar (SPA) (28) for $48 \mathrm{~h}$ at $28^{\circ} \mathrm{C}$ before use. The effect of ASM treatment on development of racechange mutants was determined using bacterial strains having two different plasmid-borne functional $a v r$ genes, avrBs 1 (strain Xav 43, race 2) and $a v r B s 3$ (strains Xav 314 and Xav 316, race 4) (Table 1). For studies of multiplication of bacteria in planta and of electrolyte leakage, a strain with an active avrBs 1 gene (Xav 43, race 2) was used as well as a putative near-isogenic strain obtained from it by spontaneous mutation from plants grown in the greenhouse (strain Xav M25, race 3) (Table 1). In Xav M25, avrBs 1 was shown to be rendered nonfunctional by the insertion sequence $I S 476$. Mutations in avrBs $I$ cause a change from race 2 to race 3 .

Plant material. Studies of race-change mutants that overcome $R$ gene $B s l$ were conducted using Early Calwonder (ECW, universal suscept) and near-isogenic line ECW-10R (has Bs1) (Table $1)$. Studies with strains that overcome $R$ gene $B s 3$ were conducted on four pepper genotypes: no major $R$ genes (cv. Camelot), only $B s 3$ (ECW-30R), Bs3 with a second (but defeated) $R$ gene (cv. Sentinel, $B s 1$ and $B s 3$ ), or $B s 3$ with two defeated $R$ genes (experimental hybrid line 6015, $B s 1, B s 2$, and $B s 3$ ) (Table 1).

Detection of avrBs1 race-change mutants. Mutations in the avrBsl gene were detected using a site-selected insertion tech- nique (7). Race-change mutants arise by the insertion of IS476 into the avrBs 1 locus $(12,13,17)$, although loss of the plasmid carrying the avrBsl locus is possible. A forward primer, designated ISF2 (TCC TCC ATG CCG AAC GAC ACC), was designed to anneal starting at nucleotide 662 in IS476. The reverse primer, AVRBS1R (ACC GCC AAG GCA CGA GAT TCA CC) was designed to anneal starting at nucleotide 1674 of $a v r B s l$, in the open reading frame (ORF) 2 of avrBsl. Insertion of IS476 in the ORF2 abolishes completely the avrBsl hypersensitivity-eliciting activity (13). Only nonfunctional $a v r B s l$ caused by insertion of IS476 will produce an amplicon, whose size varies with the site of the insertion of IS476. Another forward primer, AVRBS1F (AAG TAC ATT TTC GGC TAT GAC G), in combination with reverse primer AVRBS1R amplifies 1,047 bp of the wild-type functional avrBsl gene. AVRBS1F anneals starting at nucleotide 628 of avrBs1, $85 \mathrm{bp}$ before the beginning of ORF2. When compared with the amplicon of the second set of primers, avrBs 1 mutants produce an amplicon approximately $1.2 \mathrm{~kb}$ larger than the wild type, because of IS476 (Fig. 1).

The absence of avrBs 1 mutants in the Xav 43 suspension used as inoculum was verified geno- and phenotypically. The suspension was used to perform three to five polymerase chain reactions (PCRs) using primers ISF2/AVRBS1R and AVRBS1F/ AVRBS1R. A PCR product of the expected size was obtained only with the set of primers (AVRBS1F/AVRBS1R) that allows amplification of the wild-type, functional $a v r B s 1$ gene. Also, 60 to 100 single colonies grown from the inoculum were infiltrated into ECW-10R. All the strains elicited a hypersensitive response (HR) within $24 \mathrm{~h}$.
A

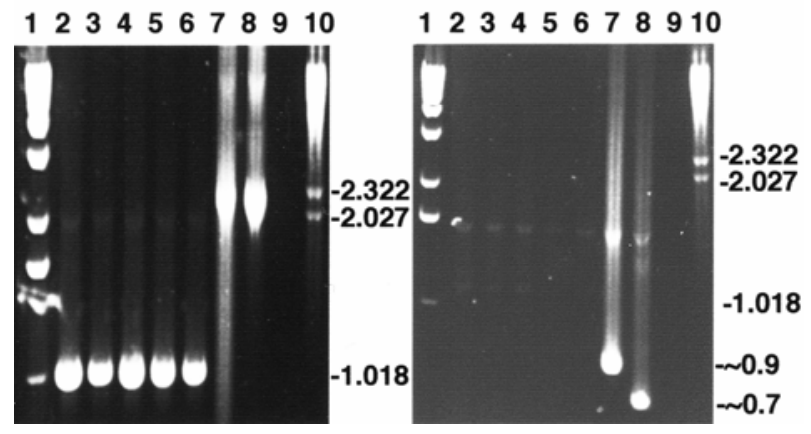

Fig. 1. A, Amplicons obtained with the set of polymerase chain reaction (PCR) primers (AVRBS1F and AVRBS1R) designed to hybridize near each end of the open reading frame 2 of $a v r B s 1$. The amplicon from the Xav 43 inoculum had an expected size of $1 \mathrm{~kb}$, whereas the avrBs 1 nonfunctional controls (Xav M25 and Xav K900) were $1.2 \mathrm{~kb}$ larger, which is the size of IS476. B, Amplicons obtained with the set of PCR primers designed to anneal near the $3^{\prime}$ end of the primary strand of avrBs 1 (AVRBS1F) and within IS476 (ISF2). The avrBs 1 locus from the Xav 43 inoculum did not amplify, whereas the nonfunctional $a v r B s 1$ controls had the expected strong bands of 670 and 900 bp. A and B, Lanes 2 to 6, Xav 43 (race 2) was used as the inoculum in the experiments; lanes 7 and 8, Xav M25 and Xav K900 (race 3); lane 9, negative control for the PCR reaction; lane 1, 1-kb ladder; and lane 10, $\lambda$ HindIII size marker.

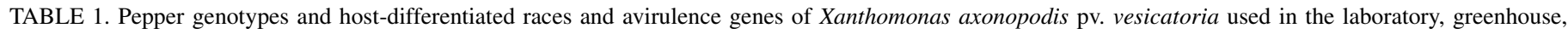
and field experiments, and expected phenotypes ${ }^{\mathrm{z}}$

\begin{tabular}{|c|c|c|c|c|}
\hline Genotypes, resistance genes & Race $2(a v r B s 1, a v r B s 2)$ & Race $3(a v r B s 2)$ & Race 4 (avrBs3) & Race 6 \\
\hline Cv. Camelot & $\mathrm{C}$ & $\mathrm{C}$ & $\mathrm{C}$ & $\mathrm{C}$ \\
\hline $\mathrm{ECW}$ & $\mathrm{C}$ & $\mathrm{C}$ & $\mathrm{C}$ & $\mathrm{C}$ \\
\hline ECW-10R $(B s l)$ & HR & $\mathrm{C}$ & $\mathrm{C}$ & $\mathrm{C}$ \\
\hline ECW-30R $(B s 3)$ & $\mathrm{C}$ & $\mathrm{C}$ & HR & $\mathrm{C}$ \\
\hline Cv. Sentinel $(B s 1, B s 3)$ & HR & $\mathrm{C}$ & $\mathrm{HR}$ & $\mathrm{C}$ \\
\hline Hybrid line $6015(B s 1, B s 2, B s 3)$ & HR & HR & HR & $\mathrm{C}$ \\
\hline
\end{tabular}

${ }^{\mathrm{z}} \mathrm{ECW}=$ Early Calwonder. Functional avirulence genes are shown in parentheses; $\mathrm{C}=$ compatible (disease), HR = incompatible hypersensitive reaction (resistance). 
Multiplication of bacteria in planta and electrolyte leakage. Plants of ECW and near-isogenic line ECW-10R were sprayed with ASM (25 mg a.i./liter) until runoff. Two weeks after spraying (previously shown to be peak of SAR activity in pepper plants; 31 ), treated and nontreated controls were infiltrated with two strains of $X$. axonopodis pv. vesicatoria, Xav 43 (race 2) and Xav M25 (race 3) (Table 1). The strains were infiltrated into opposing halves of a leaf at an initial concentration of $10^{4} \mathrm{CFU} / \mathrm{ml}$, using a needleless syringe. A leaf was removed every 2 days, and a $1-\mathrm{cm}^{2}$ disk was macerated in $1.0 \mathrm{ml}$ of sterile distilled water. The bacterial population size was estimated using dilution plating. This experiment was repeated six times, with a minimum of four plants per treatment.

Electrolyte leakage was determined using the same bacterial strains and pepper genotypes, but with a bacterial suspension of $10^{8} \mathrm{CFU} / \mathrm{ml}$ for the infiltrate. An increase in electrolyte leakage, which is associated with an alteration in the plant cell membrane, was estimated by an increase in conductivity of plant fluids (10). This experiment was repeated five times.

Race-change mutants on plants infiltrated with avirulent bacteria. Two weeks after spraying ECW and ECW-10R plants with ASM (25 mg a.i./liter), whole leaves of ASM-sprayed and nonsprayed control plants were infiltrated with the race 2 strain Xav 43, avirulent on ECW-10R, at a concentration of $2 \times$ $10^{4} \mathrm{CFU} / \mathrm{ml}$. The population size of bacteria in planta was estimated by dilution plating as previously described. After 4 weeks, necrotic HR-like lesions and larger, expanding, water-soaked lesions similar to compatible interactions were counted on leaves of ECW-10R plants using a stereoscopic microscope in the laboratory. Isolations were made from both types of lesions, and the presence of avrBs 1 race-change mutants was determined by the inability of isolated bacteria to elicit an HR on infiltrated ECW-10R plants, and by using the ISF2/AVRBS1R and AVRBS1F/AVRBS1R sets of primers to confirm a nucleotide change in the avrBsl locus, as previously described. Surface area of each leaf was determined (area meter Model LI-3100C, Li-Cor Biosciences, Lincoln, NE) and used to calculate the mean number of lesions per square centimeter.

Race-change mutants on plants inoculated by rainfall simulation. ECW and ECW-10R plants were sprayed with ASM (25 mg a.i./liter) at the growth stage of two fully expanded true leaves, or left nontreated as controls. Two weeks later, two plants per treatment were placed in plastic chambers (eight plants per chamber) in the greenhouse. This experiment was repeated three times. In the first two experiments, a susceptible ECW plant inoculated 2 weeks earlier with race 2 strain Xav 43 was placed in the center of each of 20 chambers. The day the experiment was started, a handheld sprayer was used to spray water over the inoculum plant for $8 \mathrm{~s}(12 \mathrm{ml})$ to provide water dispersal of the pathogen simulating that caused by rainfall. In the third experiment, inoculation was done by spraying an inoculum suspension (Xav 43, $2 \times 10^{5} \mathrm{CFU} / \mathrm{ml}$ ) for $4 \mathrm{~s}$ over the plants in each of 10 chambers (equivalent to approximately $7.0 \mathrm{ml} /$ chamber).

In all experiments, the chambers remained closed the first $48 \mathrm{~h}$ after inoculation, and the top remained open thereafter. The number of compatible water-soaked lesions on susceptible ECW, and incompatible hypersensitive-like lesions on resistant ECW-10R plants, was counted weekly. At 3 to 5 weeks after inoculation, expanding, water-soaked lesions were observed on ECW-10R plants. These lesions were counted and removed with a sterile scalpel, and isolations were made on modified SPA. Race-change mutants were verified genotypically (Fig. 1) and by infiltration into ECW10R plants and evaluated for their inability to elicit an HR. Five single colonies were tested per lesion. The diameter of the lesions on ECW ASM-sprayed and nonsprayed plants was measured for 90 lesions per treatment using 10 plants.

Isolation of race-change mutants in the field. In the 1997 experiment, three pepper genotypes were planted at the Sandhills
Research Station in North Carolina: cvs. Camelot and Sentinel and experimental hybrid line 6015 (Table 1). The experiment was repeated in 1998, with the addition of the near-isogenic line ECW-30R (Table 1). In both years, plants were grown from seed in the greenhouse for 7 weeks and transplanted to the field during the first week of May. No evidence of bacterial spot was observed on the plants and they were presumed free of bacterial spot. Patterns of disease development in the field after inoculation also supported this assumption, with disease developing only from the inoculation foci. Plots consisted of three rows with nine plants per row. There were $112 \mathrm{~cm}$ between rows and $35 \mathrm{~cm}$ between plants within a row. The plots were arranged in a split-plot design having four blocks, with ASM treatment as the whole plot and cultivars as the subplot. Plots remained as nonsprayed controls or were sprayed every 2 weeks with ASM (17 g a.i./ha) using a motorized ("Highboy") sprayer calibrated to deliver 607 liters/ha at 50 psi. Sprays were applied using three flat-fan nozzles per row, one over the top center of the row and two drop nozzles on each side of the row. One week after transplanting, the plant in the center of the central row was inoculated by dipping the upper third of the plant in an inoculum suspension $\left(10^{8} \mathrm{CFU} / \mathrm{ml}\right.$, with $0.04 \%$ Silwet L-77) containing two strains of race 4 (Xav 314 and Xav 316, which carry functional avrBs3) (Table 1). Mutations in $a v r B s 3$ determine a change from race 4 to race 6 . An indication of the absence of $a v r B s 3$ mutants in the inoculum was obtained by plating a sample of inoculum on modified SPA, infiltrating a minimum of 90 single colonies into ECW-30R plants maintained in the laboratory, and verifying the development of hypersensitive lesions. No race-change mutants were detected. Also, no racechange mutants were detected on samples taken from the inoculum plants in the susceptible Camelot plots, 4 and 6 weeks after inoculation. Beginning 4 weeks after inoculation, and then every 2 to 4 weeks, the incidence and severity of disease on each plant was evaluated and diseased leaf samples collected from each plot. Each sample consisted of five diseased leaves taken from five random plants (excluding the inoculated plants) for a total of 25 leaves per plot. Ten single colonies were isolated per sample and infiltrated into ECW-30R to test for the development of an HR. For plasmid-borne avrBs3, race-change mutant strains in the laboratory and the field have been shown to occur by loss of the plasmid $(2,17,22)$ and in the field also, presumably, by inactivation of the gene by an unidentified putative IS element (17). Bacterial suspensions from field isolates were blotted on a nylon membrane and hybridized with a labeled avrBs3 probe. The avrBs3 probe, a 3.3-kb BamHI fragment of the gene (2), was labeled with digoxigenin using the Genius nonradioactive detection method (Genius kit protocol; Boehringer Mannheim Biochemicals, Indianapolis, IN). The blots were washed under stringent conditions $\left(65^{\circ} \mathrm{C}, 0.5 \times \mathrm{SSC}[1 \times \mathrm{SSC}\right.$ is $0.15 \mathrm{M}$ sodium chloride plus $0.015 \mathrm{M}$ sodium citrate, $\mathrm{pH} 7.0]$, and $0.1 \%$ sodium dodecyl sulfate).

Disease was evaluated on each plant every 1 to 2 weeks for a total of seven evaluations and this data was used to calculate the mean disease rating for each plot. Disease severity was rated using a 0 -to- 9 scale defined as $0=$ no disease, $1=<1 \%$ leaf area diseased; $2=1$ to $10 \%$ leaf area diseased; $3=11$ to $20 \%$ leaf area diseased or defoliated; $4=21$ to $35 \%$ leaf area diseased or defoliated; $5=36$ to $50 \%$ leaf area diseased or defoliated; $6=51$ to $65 \%$ leaf area diseased or defoliated; $7=66$ to $80 \%$ leaf area diseased or defoliated; $8=81$ to $99 \%$ leaf area diseased and one to three remaining leaves on plant; and $9=100 \%$ of plant covered with lesions, plant dying or dead, complete defoliation (18). The areas under the disease progress curves (AUDPCs) were calculated (4).

Data analysis. Treatment effects were evaluated by using the general linear models (GLM) procedure of SAS (version 7; SAS Institute, Cary, NC). Means were separated with least squares estimates of marginal means (LSMEANS statement). 


\section{RESULTS}

Multiplication of bacteria in planta and electrolyte leakage. Multiplication of bacteria (Xav 43) in susceptible ECW plants sprayed with ASM was reduced several-fold compared with ECW plants not sprayed with ASM (Fig. 2A). In contrast, multiplication of the same bacterial strain (Xav 43, race 2, carries avrBsl) in plants resistant to this strain (ECW-10R, carries Bs1) sprayed with ASM was similar to the ASM nonsprayed plants (Fig. 2B). As expected, the increase in electrolyte leakage caused by virulent bacteria in the compatible interaction developed slower (Fig. 2C) than that caused by avirulent bacteria in the incompatible interaction (Fig. 2D). It occurred at 30 to $48 \mathrm{~h}$ after infiltration in the compatible interaction, contrasted with 9 to $24 \mathrm{~h}$ in the incompatible interaction. In both situations, however, plants sprayed with ASM had a delayed electrolyte leakage compared with nonsprayed plants (Fig. 2C and D). Also, the HR tissue collapse elicited by the avirulent bacteria in ECW-10R was visible $\approx 6$ to $12 \mathrm{~h}$ later on ASM-sprayed plants than on nonsprayed plants.

Race-change mutants in plants infiltrated with avirulent bacteria. Four weeks after inoculation, ECW-10R plants infiltrated with the avirulent strain (Xav 43, avrBsl race 2) exhibited
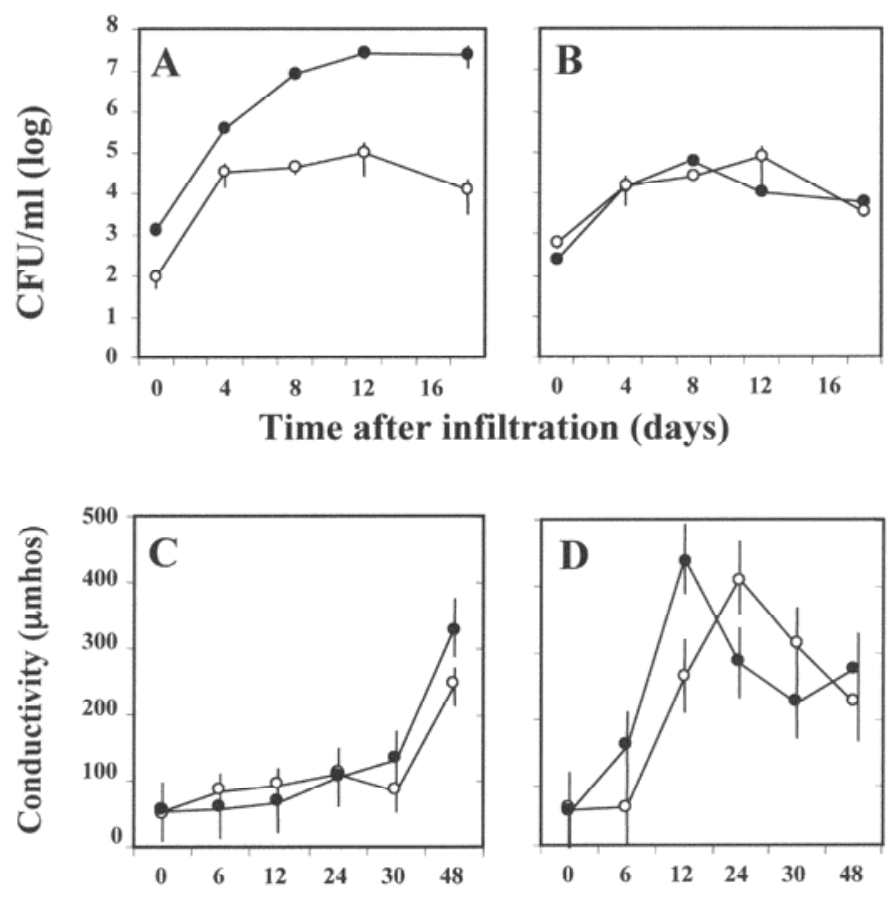

Time after infiltration (h)

Fig. 2. Multiplication curves of Xanthomonas axonopodis pv. vesicatoria strain Xav 43 in leaves of $\mathbf{A}$, compatible Early Calwonder (ECW) and $\mathbf{B}$, incompatible ECW-10R, and electrolyte leakage for $\mathbf{C}$, compatible ECW and D, incompatible ECW-10R. Plants were sprayed (open circles) or not sprayed (closed circles) with Actigard 50WG (acibenzolar-S-methyl, $17.0 \mathrm{~g}$ a.i./ha) 2 weeks prior to bacterial infiltration. Vertical bars at data points indicate the standard error. small $(<1.0 \mathrm{~mm})$, necrotic HR-like lesions (designated HR flecks), caused by the avirulent bacteria, as well as larger, expanding, water-soaked lesions similar to those of the compatible interactions (designated disease lesions) caused by putative avrBsl race-change mutants. ASM-treated plants had approximately half the number of HR flecks and disease lesions as the nonsprayed controls (Table 2). The proportion of disease lesions to HR flecks in which avrBs 1 race-change mutants were detected was similar for both ASM-sprayed $(0.20 / 13.7=0.015)$ and nonsprayed plants $(0.46 / 20.4=0.023)$ (Table 2$)$. The presence of avrBs 1 racechange mutants in disease lesions was verified by the inability of the isolated bacteria to elicit an HR when infiltrated into ECW10R plants.

Race-change mutants in plants inoculated by simulated rainfall or inoculum spray. ASM spray-inoculated plants maintained in plastic chambers in the greenhouse had $\approx 90 \%$ fewer lesions (both HR flecks and disease lesions, calculations from data in Table 2) than did nonsprayed plants (Table 2). Racechange mutants on ECW-10R were first detected 3 to 5 weeks after inoculation. Lesions harboring race-change mutants were detected 10 times more frequently on nonsprayed plants than on ASM-sprayed plants (Table 2). The proportion of disease lesions to HR flecks in which avrBs 1 race-change mutants were detected was similar for both ASM-sprayed $(0.3 / 8=0.038)$ and nonsprayed plants $(3.0 / 75=0.040)$ (Table 2). At 5 and 6 weeks after inoculation, 110 lesions were assayed from ASM-sprayed and nonsprayed plants. In only one lesion on ASM-sprayed ECW plants was a race-change mutant detected, and this mutant was mixed with strains of race 2. Lesions on ECW plants sprayed with ASM were significantly smaller in size than lesions on nonsprayed plants $(P<0.0001)$; mean lesion size on ASM-sprayed plants was $0.5 \mathrm{~mm}$ in width; whereas, on nonsprayed plants, the mean width was $2.3 \mathrm{~mm}$. Reduced lesion size most likely resulted from reduced bacterial multiplication.

Isolation of race-change mutants in the field. In the 1997 experiment, avrBs3 race-change mutants (i.e., race 6) were isolated first from diseased leaf samples 4 weeks after the inoculum was placed in the plots (Fig. 3). The frequency of detection of race-change mutants, measured by both the number of bacterial strains and the number of plots in which mutants were isolated, remained less in ASM-sprayed than nonsprayed plots until at least 8 weeks after inoculation. On susceptible, nonsprayed Camelot plants, avrBs3 race-change mutants were detected in only one plot. Mutants represented 2.5 and $7.5 \%$ of the bacterial strains assayed 6 and 8 weeks after inoculation, respectively. Only one avrBs 3 race-change mutant was detected 6 weeks after inoculation in one plot of Camelot sprayed with ASM, and none thereafter. No avrBs 3 race-change mutants were detected in samples 4 and 6 weeks after inoculation on the inoculated plants in sprayed or nonsprayed Camelot plots. In contrast, avrBs3 race-change mutants were detected on Sentinel and hybrid line 6015 inoculated plants 4 weeks after inoculation in both nonsprayed and ASM-sprayed plots. Dot-blot hybridization performed on 240 strains using avrBs3 as a probe indicated that none of these mutants carried the avrBs3 gene (data not shown) and so, presumably, had lost the plasmid carrying avrBs3.

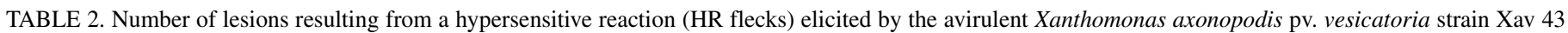

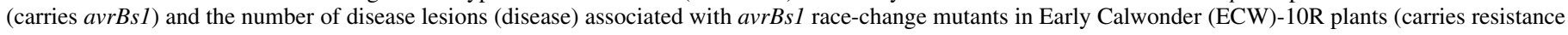
gene $B s 1$ and is resistant to $\operatorname{Xav} 43)^{\mathrm{z}}$

\begin{tabular}{|c|c|c|c|c|}
\hline \multirow[b]{2}{*}{ Treatment } & \multicolumn{2}{|c|}{ Mean number lesions $/ \mathrm{cm}^{2}$ of leaf using syringe infiltration } & \multicolumn{2}{|c|}{ Mean number lesions/plant using spray inoculation } \\
\hline & HR flecks & Disease & HR flecks & Disease \\
\hline Control, non-ASM sprayed & $20.4 \mathrm{a}$ & $0.46 \mathrm{a}$ & $75 \mathrm{a}$ & $3.0 \mathrm{a}$ \\
\hline ASM sprayed & $13.7 \mathrm{a}$ & $0.20 \mathrm{~b}$ & $8 \mathrm{~b}$ & $0.3 \mathrm{~b}$ \\
\hline
\end{tabular}

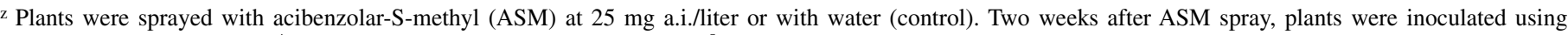
syringe infiltration $\left(2 \times 10^{4} \mathrm{CFU} / \mathrm{ml}\right)$ or by spraying inoculum $\left(2 \times 10^{5} \mathrm{CFU} / \mathrm{ml}\right)$ directly onto the foliage. Lesions, both HR flecks and disease, were counted 4 weeks after inoculation. Means within each column followed by the same letter do not significantly different at $P=0.05$. 
The severity of bacterial spot, measured as AUDPC, was significantly reduced in Camelot and experimental hybrid line 6015 plots sprayed with ASM, compared with nonsprayed plots $(P=0.0001$ and 0.0219 , respectively), and only marginally in sprayed plots of Sentinel compared with nonsprayed plots $(P=$ 0.0751) (Table 3).

In the 1998 experiment, all the nonsprayed resistant genotype plots had race-change mutants 4 (ECW-30R) or 6 (Sentinel, line 6015) weeks after inoculation (Fig. 4). Race-change mutants were first isolated from all ASM-sprayed plots 6, 8, or 13 weeks after inoculation on hybrid line 6015, ECW-30R, and Sentinel, respectively. One avrBs 3 race-change mutant strain was detected from a nonsprayed plot and one from an ASM-sprayed plot of Camelot, both 10 weeks after inoculation (Fig. 4). Using dot blot hybridization, $a v r B s 3$ was detected in 5 (from an ECW-30R plot sprayed with $\mathrm{ABM}$ ) of 95 strains assayed as having a race-change mutant phenotype (data not shown). As in 1997, the severity of disease was significantly reduced in all pepper genotypes sprayed with ASM compared with nonsprayed controls (Table 3).

\section{DISCUSSION}

The lack of an appropriate resistant gene deployment strategy can render existing resistant cultivars susceptible within a few cropping seasons. Resistance-inducing chemicals have shown efficacy for the control of several plant diseases. It has been proposed that plant defense activators may prolong the useful life of resistance genes and fungicides presently used (26). Such activators are suitable within an integrated management strategy, used in conjunction with other control methods (20). Previously, we reported the efficacy of ASM for the control of bacterial spot of bell pepper and its possible use to complement copper bactericide applications in the field (31). Now we present evidence that SAR may prolong the durability of genotype-specific disease resistance.

The use of ASM reduced the frequency of lesions associated with avrBs 1 race-change mutants on pepper plants carrying $R$ gene Bsl and inoculated with an avirulent strain of $X$. axonopodis pv. vesicatoria. ASM-sprayed plants had 57 and $90 \%$ fewer disease lesions associated with avrBs 1 race-change mutants than nontreated plants on infiltrated and spray-inoculated plants, respectively (Table 2).

Not only were fewer disease lesions associated with avrBsl race-change mutants on ASM-sprayed resistant plants (ECW-10R, $B s 1$ gene) than nonsprayed plants, but also HR flecks caused by the avirulent bacteria were fewer. With both methods, syringe infiltration and spray inoculation, the frequency of race-change mutant-associated lesions to HR flecks was similar for both ASMsprayed resistant plants and nonsprayed resistant plants. In one of the HR lesions, we detected a mixture of avirulent race 2 and avrBsl race-change mutant strains, suggesting that race-change mutants can arise within HR lesions. Spontaneous mutations may occur at higher rates in dying tissues. If this were the case, the fewer the HR flecks, the less the likelihood of race-change mutants. SAR, through reducing the number of HR flecks by suppressing bacterial multiplication (Fig. 2) and, thus, the bacterial population size, may reduce the selection pressure exerted by a single $R$ gene, which may explain the reduction in race change mutants detected.

On susceptible ECW plants sprayed with ASM, there was a reduction in the number and size of disease lesions compared with the nonsprayed plants. This was accompanied by reduced multiplication of bacteria on ASM-sprayed plants. On resistant plants,

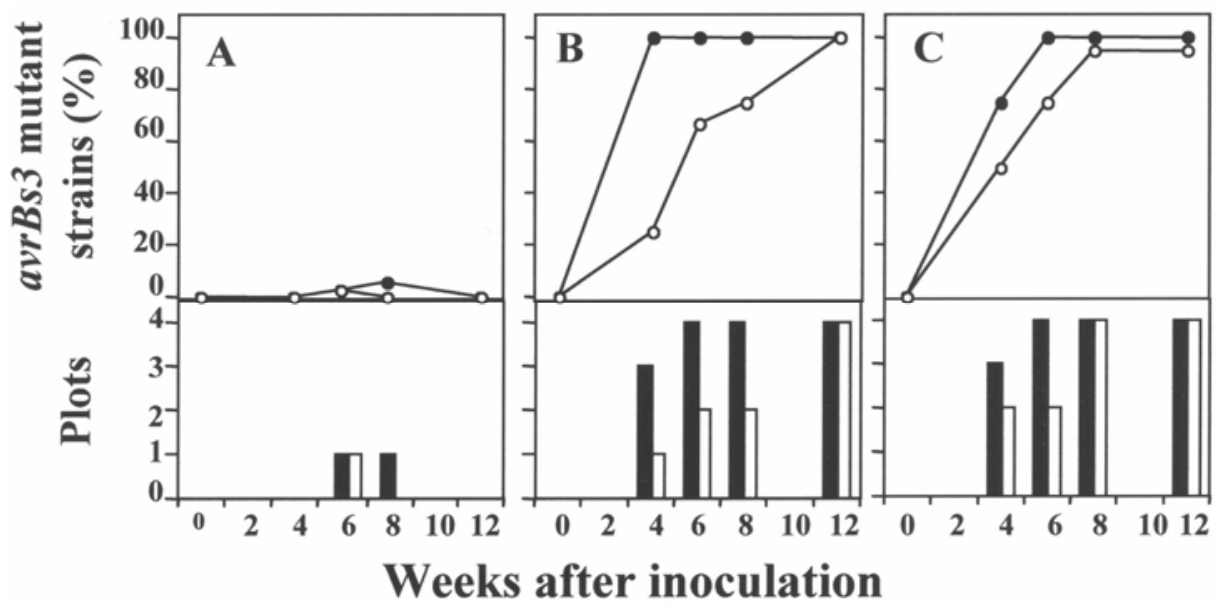

Fig. 3. Frequency of $a v r B s 3$ race-change mutants (i.e., race 6) during a 12-week period following the introduction of race 4 strains Xav 314 and Xav 316 of Xanthomonas axonopodis pv. vesicatoria into 1997 field plots. Plots were sprayed (open circles) or not sprayed (closed circles) with Actigard 50WG (acibenzolar$S$-methyl [ASM], $17.0 \mathrm{~g}$ a.i./ha) every 2 weeks. A, Cv. Camelot (no resistance $[R]$ genes); B, cv. Sentinel ( $R$ genes $B s 1$ and $B s 3)$; and $\mathbf{C}$, hybrid line 6015 ( $R$ genes $B s 1, B s 2$, and Bs3). Bottom portion of each graph corresponds to the number of plots treated (white bars) or nontreated (black bars) with ASM where race-change mutants were detected; there were four plots assayed per genotype.

TABLE 3. Severity of bacterial spot, expressed as area under disease progress curve (AUDPC), on bell pepper genotypes inoculated with Xanthomonas axonopodis pv. vesicatoria strains Xav 314 and Xav 316 (race 4, carry avrBs3) ${ }^{2}$

\begin{tabular}{lcccc}
\hline Year, treatment & Cv. Camelot & ECW-30R $(B s 3)$ & Cv. Sentinel $(B s 1, B s 3)$ & Hybrid line 6015 $(B s 1, B s 2, B s 3)$ \\
\hline 1997 & $104 \mathrm{a}$ & $\ldots$ & $20 \mathrm{a}$ & $21 \mathrm{a}$ \\
Nonsprayed & $62 \mathrm{~b}$ & $\ldots$ & $13 \mathrm{a}$ & $12 \mathrm{~b}$ \\
ASM sprayed & $110 \mathrm{a}$ & $32 \mathrm{a}$ & $33 \mathrm{a}$ & $35 \mathrm{a}$ \\
1998 & $83 \mathrm{~b}$ & $9 \mathrm{~b}$ & $6 \mathrm{~b}$ & $11 \mathrm{~b}$ \\
Nonsprayed & ASM sprayed & & $\ldots$ & \\
\hline
\end{tabular}

${ }^{z}$ Plots were sprayed or not sprayed with acibenzolar-S-methyl (ASM, $17 \mathrm{~g}$ a.i./ha, Actigard 50WG) every 2 weeks, at Sandhills Research Station, North Carolina, 1997 and 1998. Early Calwonder (ECW)-30R was not included in the 1997 experiment. Within each column and year, means followed by the same letter are not significantly different at $P=0.05$. 
in contrast, although the number of HR lesions was greatly reduced by the use of ASM, the reduction of multiplication of avirulent bacteria was almost negligible. The lack of a further decrease on avirulent bacterial multiplication suggests that the induction of systemic resistance and function of $R$ gene resistance do not have additive effects; instead, SAR appears to be an epistatic effect to gene-for-gene resistance. Reduction of necrotic symptoms (disease and HR flecks) on ASM-treated plants compared with nontreated plants was accompanied by a delay in electrolyte leakage and tissue collapse caused by both virulent and avirulent strains. Biological inducers of local resistance (e.g., bacterial lipopolysaccharide) that give protection to bacterial spot-causing strains on bell pepper (29) also prevented the HR by avirulent strains (24). In the Arabidopsis hrll mutant, constitutive SAR expression suppressed HR-associated cell death; whereas, on wild-type Arabidopsis plants, ASM and SA treatments strongly reduced the electrolyte leakage induced by an avirulent bacterial pathogen (8). When an avirulent pathogen attacks a plant, the host needs to control the spread of HR cell death. Reduction of HR in systemically protected plants may represent this negative feedback loop that controls the extent of cell death at the site of infection, and further defense induction. In contrast to these results, supplementation of SA in soybean suspension cultures accelerated and increased the amount of cell death induced by an avirulent strain of $P$. syringae pv. glycinea (34), whereas transformed tobacco plants that did not express SA had a delayed HR and electrolyte leakage during Tobacco mosaic virus infections (23). These conflicting results may be the consequence of differences
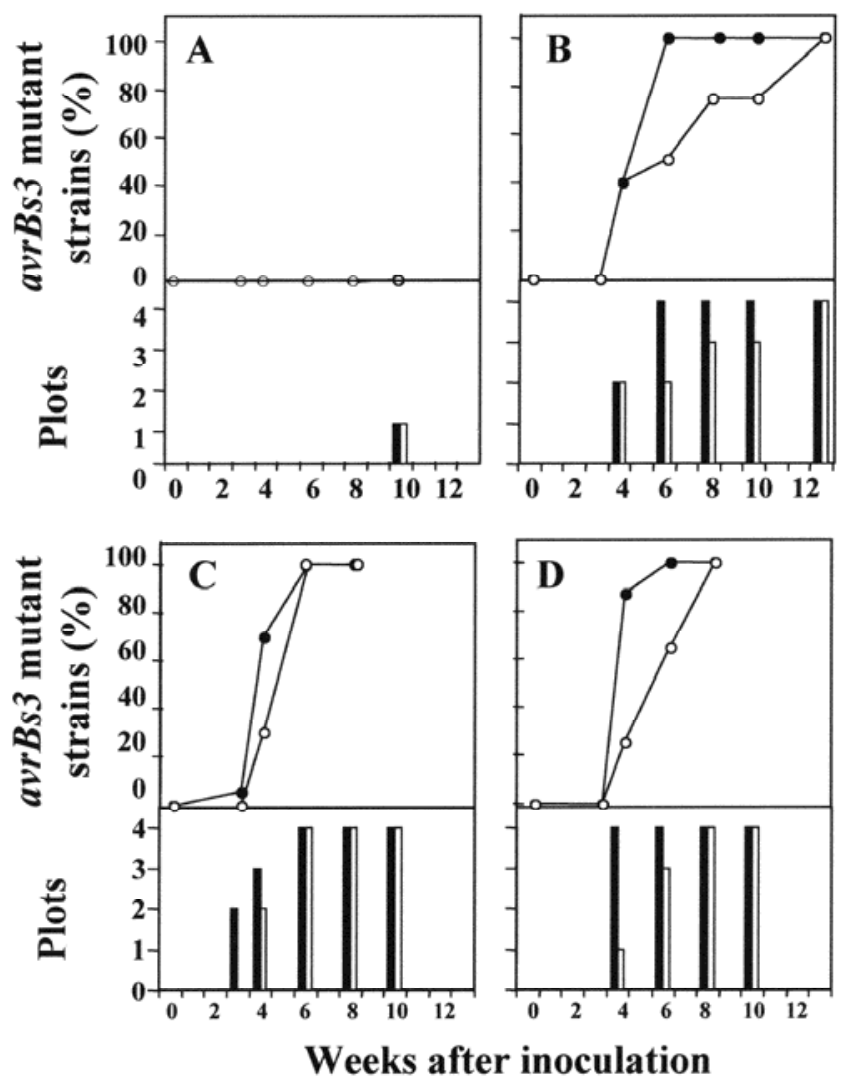

Fig. 4. Frequency of avrBs3 race-change mutants (i.e., race 6) during a 12-week period following the introduction of race 4 strains Xav 314 and Xav 316 of Xanthomonas axonopodis pv. vesicatoria into 1998 field plots. Plots were treated (open circles) or not treated (closed circles) with Actigard 50WG (acibenzolar-S-methyl [ASM], $17.0 \mathrm{~g}$ a.i./ha) every 2 weeks. A, Cv. Camelot (no resistance $[R]$ genes); B, cv. Sentinel ( $R$ genes $B s l$ and $B s 3$ ); C, hybrid line 6015 ( $R$ genes $B s 1, B s 2$, and $B s 3)$; and D, Early Calwonder-30 R ( $R$ gene $B s 3)$. Bottom part of each graph corresponds to the number of plots sprayed (white bars) or nonsprayed (black bars) with ASM where race-change mutants were isolated; there were four plots assayed per genotype. in the signaling pathways induced by SA and ASM, as occurs in wheat (33), or by 2,6-dichloroisonicotinic acid versus biological inducers in barley (15).

In our field experiments, the detection of race-change mutants on plants carrying an effective $R$ gene and sprayed with ASM was delayed compared with similar non-ASM-sprayed plants. The combination of major $R$ genes and ASM also was effective in reducing the severity of bacterial spot. Using a different set of avirulence-resistance genes $(a v r B s 3-B s 3)$ than the one used in the greenhouse experiments, race-change mutants were detected up to 6 weeks later in ASM-sprayed plots than in nonsprayed plots.

The frequency of detection of $a v r B s 3$ race-change mutants was very low on Camelot plants in both years. Camelot is a hybrid susceptible to all known bacterial spot strains and, thus, it should not impose a selection for race-change mutants. Similarly, a low frequency of race-change mutants was observed on the susceptible ECW in the greenhouse experiments.

There also appears to be a relationship between induction of systemic resistance and multigenic (horizontal, nongenotypespecific) resistance (37). SAR in plants seems to shift defense mechanisms from a latent state to a state of resistance observed in plants carrying multiple genes for resistance (37). If this is correct, then observations on extending the durability of major $R$ genes by activation of systemic resistance, as indicated in this article, also could be pertinent to plants exhibiting multigenic or nongenotype-specific resistance and the delay in occurrence of race-change mutants to major $R$ gene resistance carried by such plants.

In summary, the use of ASM, an activator of systemic resistance, reduced the frequency of isolation of $a v r B s 1$ and $a v r B s 3$ race-change mutants on pepper plants containing the major $R$ genes $B s 1$ and $B s 3$, respectively, in the greenhouse, the laboratory, and the field. Although this inducer of innate host resistance did not prevent the occurrence of race-change mutants in plants carrying major resistance genes, induced resistance was associated with a delay in detection of such mutants, and with reduced disease severity when they did occur. Thus, inducers of plant disease resistance could be an important tool to prolong the usefulness of major resistance genes, especially for pathogens with a history of adaptation to such genes. A possible mechanism for this delay in occurrence of race-change mutants may be the lack of specific selection pressure. Evidence from use of different pathogen races and strains (here and unpublished data) indicates that the plants that demonstrate the induced state of resistance are pathogen race and strain neutral. Thus, ASM-treated plants would provide a nonspecific selection for all races and strains, including the racechange mutants that may occur. Also, some of these race-change mutants are likely to have reduced aggressiveness and, thus, may be more quickly eliminated from the pathogen population than the wild-type, non-race-change mutants, which would continue to be controlled by the major $R$ gene resistance.

\section{ACKNOWLEDGMENTS}

This research was supported in part by an NRI Competitive Grants Program/United States Department of Agriculture Agreement 96-353133621 and by the North Carolina Agricultural Research Service. We thank C. S. Kousik for providing the primers ISF2, AVRBS1F, and AVRBS1R that he designed, and for all his helpful comments; and T. Abernethy, D. W. Pollard, and the staff at Sandhills Research Station for their assistance with different aspects of this project.

\section{LITERATURE CITED}

1. Bergelson, J., Kreitman, M., Stahl, E. A., and Tian, D. 2001. Evolutionary dynamics of plant R-genes. Science 292:2281-2285.

2. Bonas, U., Stall, R. E., and Staskawicz, B. J. 1989. Genetic and structural characterization of the avirulence gene avrBs3 from Xanthomonas campestris pv. vesicatoria. Mol. Gen. Genet. 218:127-136. 
3. Bousset, L., and Pons-Kühnemann, J. 2003. Effects of acibenzolar-Smethyl and ethirimol on the composition of a laboratory population of barley powdery mildew. Phytopathology 93:305-315.

4. Campbell, C. L., and Madden, L. V. 1990. Introduction to Plant Disease Epidemiology. John Wiley \& Sons, New York.

5. Cook, A. A., and Guevara, Y. G. 1984. Hypersensitivity in Capsicum chacoense to race 1 of the bacterial spot pathogen of pepper. Plant Dis. 68:329-330.

6. Cook, A. A., and Stall, R. E. 1963. Inheritance of resistance in pepper to bacterial spot. Phytopathology 53:1060-1062.

7. Cooley, M. B., Goldsbrough, A. P., Still, D. W., and Yoder, J. I. 1996. Siteselected insertional mutagenesis of tomato with maize Ac and Ds elements. Mol. Gen. Genet. 252:184-194.

8. Devadas, S. K., and Raina, R. 2002. Preexisting systemic acquired resistance suppresses hypersensitive response-associated cell death in Arabidopsis hrl1 mutant. Plant Physiol. 128:1234-1244.

9. Hammerschmidt, R., Metraux, J.-P., and van Loon, L. C. 2001. Inducing resistance: A summary of papers presented at the first international symposium on induced resistance to plant diseases, Corfu, May 2000. Eur. J. Plant Pathol. 107:1-6.

10. Hibberd, A. M., Stall, R. E., and Bassett, J. J. 1987. Different phenotypes associated with incompatible races and resistance genes in bacterial spot disease of pepper. Plant Dis. 71:1075-1078.

11. Hulbert, S. H., Webb, C. A., Smith, M., and Sun, Q. 2001. Resistance gene complexes: Evolution and utilization. Annu. Rev. Phytopathol. 39:285-312.

12. Kearney, B., Ronald, P. C., Dahlbeck, D., and Staskawicz, B. J. 1988. Molecular basis for evasion of plant host defense in bacterial spot disease of pepper. Nature 332:541-543.

13. Kearney, B., and Staskawicz, B. J. 1990. Characterization of IS476 and its role in bacterial spot disease of tomato and pepper. J. Bacteriol. 172:143148.

14. Kim, B. S., and Hartmann, R. W. 1985. Inheritance of a gene (Bs3) conferring hypersensitive resistance to Xanthomonas campestris pv. vesicatoria in pepper (Capsicum annuum). Plant Dis. 69:233-235.

15. Kogel, K.-H., Beckhove, U., Dreschers, J., Münch, S., and Rommé, Y. 1994. Acquired resistance in barley. Plant Physiol. 106:1269-1277.

16. Kousik, C. S., and Ritchie, D. F. 1995. Isolation of pepper races 4 and 5 of Xanthomonas campestris pv. vesicatoria from diseased peppers in Southeastern U.S. fields. Plant Dis. 79:540.

17. Kousik, C. S., and Ritchie, D. F. 1996. Race shift in Xanthomonas campestris pv. vesicatoria within a season in field-grown pepper. Phytopathology 86:952-958.

18. Kousik, C. S., Sanders, D. C., and Ritchie, D. F. 1996. Mixed genotypes combined with copper sprays to manage bacterial spot of bell peppers. Phytopathology 86:502-508.

19. Louws, F. J., Wilson, M., Campbell, H. L., Cuppels, D. A., Jones, J. B., Shoemaker, P. B., Sahin, F., and Miller, S. A. 2001. Field control of bacterial spot and bacterial speck of tomato using a plant activator. Plant Dis. $85: 481-488$

20. Lyon, G. D., and Newton, A. C. 1999. Implementation of elicitor mediated induced resistance in agriculture. Pages 299-318 in: Induced Plant Defenses Against Pathogens and Herbivores. Biochemistry, Ecology, and Agriculture. A. A. Agrawal, S. Tuzun, and E. Bent, eds. The American Phytopathological Society Press, St. Paul, MN.
21. Marco, G. M., and Stall, R. E. 1983. Control of bacterial spot of pepper initiated by strains of Xanthomonas campestris pv. vesicatoria that differ in sensitivity to copper. Plant Dis. 67:779-781.

22. Minsavage, G. V., Dahlbeck, D., Whalen, M. C., Kearney, B., Bonas, U., Staskawicz, B. J., and Stall, R. E. 1990. Gene-for-gene relationships specifying disease resistance in Xanthomonas campestris pv. vesicatoriapepper interactions. Mol. Plant-Microbe Interact. 3:41-47.

23. Mur, L. A., Bi, Y.-M., Darby, R., Firek, S., and Draper, J. 1997. Compromising early salicylic acid accumulation delays the hypersensitive response and increases viral dispersal during lesion establishment in TMV-infected tobacco. Plant J. 12:1113-1126.

24. Newman, M. A., Daniels, M., and Dow, J. M. 1997. The activity of lipid A and core components of bacterial lipopolysaccharides in the prevention of the hypersensitive response in pepper. Mol. Plant-Microbe Interact. 10:926-928.

25. O'Garro, L. W. 1998. Bacterial spot of tomato and pepper on four east Caribbean Islands: Races, their abundance, distribution, aggressiveness, and prospects for control. Plant Dis. 82:864-870.

26. Oostendorp, M., Kunz, W., Dietrich, B., and Staub, T. 2001. Induced disease resistance in plants by chemicals. Eur. J. Plant Pathol. 107:19-28.

27. Pernezny, K., Collins, J., Stall, R. E., Shuler, K., and Datnoff, L. E. 1999. A serious outbreak of race 6 of Xanthomonas campestris pv. vesicatoria on pepper in Southern Florida. Plant Dis. 93:79.

28. Ritchie, D. F., and Dittapongpitch, V. 1991. Copper- and streptomycinresistant strains and host differentiated races of Xanthomonas campestris pv. vesicatoria in North Carolina. Plant Dis. 75:733-736.

29. Romeiro, R. S., and Kimura, O. 1997. Induced resistance in pepper leaves infiltrated with purified bacterial elicitors from Xanthomonas campestris pv. vesicatoria. J. Phytopathol. 145:495-498.

30. Romero, A. M., Kousik, C. K., and Ritchie, D. F. 1996. Characteristics of Xanthomonas campestris pv. vesicatoria race 3 strains isolated from pepper. (Abstr.) Phytopathology 86(suppl.):S78.

31. Romero, A. M., Kousik, C. S., and Ritchie, D. F. 2001. Resistance to bacterial spot in bell pepper induced by acibenzolar-S-methyl. Plant Dis. 85:189-194.

32. Sahin, F., and Miller, S. A. 1998. Resistance in Capsicum pubescens to Xanthomonas campestris pv. vesicatoria pepper race 6. Plant Dis. 82:794-799.

33. Schaffrath, U., Freydl, E., and Dudler, R. 1997. Evidence for different signaling pathways activated by inducers of acquired resistance in wheat. Mol. Plant-Microbe Interact. 10:779-783.

34. Shirasu, K., Nakajima, H., Rajasekhar, V. K., Dixon, R. A., and Lamb, C. 1997. Salicylic acid potentiates an agonist-dependent gain control that amplifies pathogen signals in the activation of defense mechanisms. Plant Cell 9:261-270.

35. Stall, R. E., Beaulieu, C., Egel, D., Hodge, N. C., Leite, R. P., Minsavage, G. V., Bouzar, H., Jones, J. B., Alvarez, A. M., and Benedict, A. A. 1994 Two genetically diverse groups of strains are included in Xanthomonas campestris pv. vesicatoria. Int. J. Syst. Bacteriol. 44:47-53.

36. Thompson, J. N., and Burdon, J. J. 1992. Gene-for-gene coevolution between plants and parasites. Nature 360:121-125.

37. Tuzun, S. 2001. The relationship between pathogen-induced systemic resistance (ISR) and multigenic (horizontal) resistance in plants. Eur. J. Plant Pathol. 107:85-93.

38. Vauterin, L., Hoste, B., Kersters, K., and Swings, J. 1995. Reclassification of Xanthomonas. Int. J. Syst. Bacteriol. 45:472-489. 